\title{
Effect of an intervention on teachers' and teaching assistants' attitudes and academic expectations concerning the educational inclusion of students with Down's Syndrome
}

\author{
Valentina Mora-Castelletto' \\ https://orcid.org/0000-0003-2415-1551 \\ María Magdalena Muñoz-Montes ${ }^{1}$ \\ https://orcid.org/0000-0002-9463-9731 \\ Francisca Pozo-Tapia ${ }^{1}$ \\ https://orcid.org/0000-0001-9667-3063 \\ Eduardo Fuentes-López ${ }^{1}$ \\ https://orcid.org/0000-0002-0141-0226 \\ Giorvan Ânderson dos Santos Alves ${ }^{2}$ \\ https://orcid.org/0000-0003-1619-0139 \\ Carla Rivera-Bahamonde ${ }^{1}$ \\ https://orcid.org/0000-0002-7130-7849
}

Pontificia Universidad Católica de Chile Facultad de Medicina, Departamento Ciencias de la Salud, Carrera de Fonoaudiología, Santiago, Chile. Universidade Federal da Paraíba - UFPB, Departamento de Fonoaudiologia, João Pessoa, Paraíba, Brasil.

Conflict of interests: Nonexistent

\section{(c) (i)}

Received on: September 29, 2021

Accepted on: November 15, 2021

Corresponding address:

Carla Rivera-Bahamonde

Carrera de Fonoaudiología, Departamento Ciencias de la Salud, Facultad de Medicina

Pontificia Universidad Católica de Chile

Avenida Vicuña Mackenna 4860, Macul

Código Postal: 7820436 - Santiago, Chile

E-mail: criverab@uc.cl

\section{ABSTRACT}

Purpose: to assess the effect of an intervention on educational teams' attitudes and academic expectations concerning the inclusion of students with Down's Syndrome (DS), in Chile.

Methods: a quasi-experimental single-group study was carried out, with an interdisciplinary pilot intervention held comprising three workshops on inclusive education for teachers and teaching assistants. The Attitudes Towards and Academic Expectations For Down's Syndrome Students questionnaire (CAEASD in Spanish) was used to assess these variables pre- and post-intervention.

Results: 48 subjects participated in this study, with 37 in the experimental group and 11 in the control group. No significant differences were observed in the overall CAEASD score, neither before nor after the intervention $(p=0.388)$. However, in the actions part of the attitude component, there was a significant difference in the experimental group $(p<0.05)$, in which, the proportion of positive changes in the overall CAEASD score was also greater than that in the control group.

Conclusion: mentoring had a positive impact on educational teams' attitudes towards students with DS, helping to develop an inclusive educational community.

Keywords: Attitude; Down's Syndrome; Education; Learning; Mentoring; Speech, Language and Hearing Sciences 


\section{INTRODUCTION}

Speech therapy, in education, plays multiple roles, from evaluating difficulties, intervening in schools and developing the curriculum, to advising and assisting their educational teams ${ }^{1}$. To achieve its aims, collaboration and interdisciplinary work is required between members of the school community, in order for this to be inclusive successfully ${ }^{2}$. There are also other factors, though, that influence the inclusion of students with special educational needs (SEN) in schools, including teachers' attitudes and academic expectations concerning people with disabilities ${ }^{3,4}$.

In this context, both educational teams' attitudes and academic expectations play a crucial role. Attitudes can be defined as a learned set of beliefs, actions and emotions $^{5}$ that determine how one person behaves towards another. Beliefs are understood as a subjective version of the truth, a conviction or something that the subject considers true ${ }^{6}$. Emotions allude to the affective link with reality, immediately assessing emotionally the person or situation ${ }^{7}$, while actions refer to each subject's behavior. For their part, academic expectations refer to what the teacher expects their students to learn regarding the curriculum ${ }^{8}$. It is important, therefore, to value educational teams' attitudes and academic expectations, since these condition children's academic performance, interest in schooling, self-esteem and relationships with their peers and teachers ${ }^{9}$.

There is evidence that sending students with DS to normal schools has a positive impact on their development, encouraging speech intelligibility and linguistic development and giving them greater opportunities for academic success and social development ${ }^{10,11}$. The support that teaching assistants provide teachers directly affects teachers' attitudes towards students with $\mathrm{DS}^{12,13}$. That is why changing educational teams' attitudes and academic expectations towards students with DS is relevant.

It has been reported that teachers are optimistic about including students with SEN in their classes, although they are also anxious, overwhelmed, unsure about and uncomfortable working with them ${ }^{14}$. This partly explains why they are not familiar with inclusion and do not have the tools required to diversify their work $^{12,15}$. It should also be added that they lack knowledge about the cognitive and behavioral characteristics that have an impact on the learning of DS students ${ }^{16}$. The lack of training available for educational teams leads to low academic expectations, making teaching difficult and causing trust and self-esteem issues among the students ${ }^{17}$.

Teacher training and professional development has a positive impact on inclusion in schools, improving acceptance of people with DS ${ }^{18}$. The latter also leads to the creation of realistic expectations and positive attitudes ${ }^{16,19,20}$. An intervention with favorable results was developed by Serrato and García ${ }^{21}$, who held a five-session course/workshop for teachers. The aim was to provide theoretical tools and teaching methods, raising teachers' awareness of diversity to increase the use of inclusive practices in the classroom. Their intervention consisted of presenting the traits of inclusive education and its implications both theoretically and practically, with activities to promote participation and reflection. However, the study sample was small and there was no control group, which means it is difficult to draw general conclusions about the intervention's effectiveness.

Lindsay and Edwards ${ }^{22}$ carried out a systematic revision of interventions for children and young people on attitudes towards and acceptance and knowledge of disability. The results showed that, in 34 of the 43 studies, participants' attitudes towards their classmates with disabilities improved. One of the studies chosen was carried out in Singapore, where university students were involved in an intervention with the aim of improving attitudes towards the inclusion of people with intellectual disabilities. The authors' intervention involved ten sessions and they observed improvements in participants' attitudes. There have been no studies of this type on interventions involving teachers' and/or teaching assistants' attitudes.

In the context of people with DS specifically, Rooney ${ }^{23}$ carried out an intervention on a group of university students. The aim was to improve attitudes and positive feelings towards people with DS by looking at photographs of individuals with DS and imagining positive interactions with them. The quality and quantity of prior contact with people with DS is associated with positive and pleasant attitudes towards them. Campbell and Gilmore's ${ }^{19}$ aim was to improve the attitudes of future teachers towards diversity and the inclusion of students with DS. The intervention was carried out at a university and involved DS content and the inclusive educational model. There was a positive change in attitudes to inclusion of people with DS. The study combined teaching based on theoretical information with structured practical examples, demonstrating that 
raising awareness about disability can lead to changes in attitudes to diversity.

Based on this, it is possible to confirm that no prior interventions to improve teachers' attitudes to students with DS exist, in spite of the fact that they are key agents to their inclusion. In addition, there is even less evidence of the modification of students' academic expectations. No studies have measured the impact of interventions on the educational team's attitudes and academic expectations as a whole, towards students with DS. As a result, this study aimed to evaluate the effect of interventions on teachers' and teaching assistants' attitudes and academic expectations, concerning the inclusion of students with DS in schools in Chile.

\section{METHODS}

A quasi-experimental single-group study was carried out, involving a pilot intervention aimed to encourage positive attitudes and expectations concerning the inclusion of students with DS in schools. Teachers and teaching assistants from one of the neighborhoods in Chile's Metropolitan Region were invited to take part.

All those recruited signed an informed consent form before taking part. The study protocol and the informed consent were approved by the Pontifical Catholic University of Chile's Ethics Committee (Protocol №: 190311007), Chile.

An non-probabilistic sample of teachers and teaching assistants was chosen from schools in the San Bernardo neighborhood of Chile's Metropolitan Region. In this area, $6.7 \%$ of students attend special needs schools, which is higher than the global average in Chile $(5.1 \%)^{24}$.

Inclusion criteria involved municipal educational establishments with School Integration Programs (SIP), since these adhere to Decree $N^{\circ} 170 / 2009$ which promotes accepting students with temporary or permanent SEN, including students with $\mathrm{DS}^{25}$. Establishments attended by DS students were also included, since this made it easier to relate the intervention to real examples and to apply the strategies taught. Head teachers, teachers and professional teaching assistants were included in order to incorporate different perspectives from within the educational community.

A questionnaire was used to collect data about the demographic and employment characteristics of those working with people with DS. In addition, the CAEASD ${ }^{26}$ survey was used to determine the sample's attitudes and expectations concerning students with DS. For details of the validation process and the questions included in the CAEASD survey, please see MuñozMontes et al. ${ }^{26}$ The CAEASD survey uses two scales, both in a Likert format with five possible answer alternatives (from 'totally agree' to 'totally disagree'). The scale for Attitudes Towards Students With Down's Syndrome (EASD in Spanish) has three subscales: beliefs, emotions and actions, while the second one evaluates Academic Expectations For Students With Down's Syndrome (EEASD in Spanish) using a single scale. This instrument has acceptable indicators for content validity, construct validity and reliability on both scales ( $a=0,88$ for the EASD and 0.86 for the EEASD scale). The survey was taken both pre- and post-intervention.

In the group that was intervened, a satisfaction survey was carried out to collect information about the intervention's positive and negative aspects. This instrument was created in-house and included ten Likert format questions, with a choice of five possible answer alternatives (from 'completely agree' to 'completely disagree'). Participants were asked to rate their satisfaction with acquisition of new knowledge, content organization, workshop methodology, speaker quality and the resources used. To determine content validity and the satisfaction survey's format, expert opinions were sought. The survey was sent to ten experts connected to educational interventions and/or to evaluation methods, six of whom responded. They agreed that the ten items that made up the survey were relevant to evaluating the construct (content validity) and that the statements were easily interpreted (format validity). The recently created instrument was called the Satisfaction Survey For Inclusivity Oriented Workshops (SSIOW).

Prior to the intervention, both groups answered the CAEASD survey and filled in the information form. The intervention was then carried out, involving a program of three workshops for the experimental group and an introductory talk for the control group. Finally, both groups were subject to a post-intervention assessment using the CAEASD survey. In addition, the intervention group answered the workshop satisfaction survey.

The intervention for the experimental group involved three theoretical-practical workshops involving content on inclusion, such as the distinction between the concepts of integration and inclusion, fact and fiction about people with DS, the Universal Design for Learning (UDL), facilitating factors and barriers to inclusion, how students with DS learn and inclusive educational and behavioral strategies for students with DS. 
Active learning methods were applied, such as team-based learning, problem solving, small-group discussions and the use of learning technology. Each workshop was run by a group of speech therapists and special needs teachers, who modeled the use of teaching strategies using the UDL. Each one lasted approximately 90 minutes and they were held over a three-month period (Appendix 1). In addition, two videos were provided as additional material.

The control group received a 45-minute introductory talk, whose aim was to provide inclusive orientation for students with Down's Syndrome. This was given by the same team of professionals and included content on inclusion, such as the distinction between the concepts of integration and inclusion, facilitating factors and barriers to inclusion and how students with DS learn. In addition, a leaflet was provided with extra material on the topics dealt with in the session.

An exploratory data analysis was carried out by looking for atypical values and determining the distribution of the continuous quantitative variables using the Shapiro- Wilk test. To display the scores of both (experimental and control) groups, box plots were used. The intragroup comparisons (of both intervened and control groups) of the scores of each of the four pre- and post-intervention fields were carried out using the Wilcoxon non-parametric signed-rank test. In order to determine which of the two groups had the greatest differences after the intervention, a variable was created by subtracting the score from that obtained from the previous intervention. Using the non-parametric Mann-Whitney test, the previously mentioned variable was compared. For all the statistical analyses, STATA version 16 software was used.

\section{RESULTS}

A total of 48 teachers and teaching assistants from two schools agreed to take part. There were 37 subjects in the experimental group and 11 in the control group. In the experimental group, there was an equal balance between teachers and teaching assistants, while in the control group, the majority (over $80 \%$ ) were teachers. In addition, in the latter, $100 \%$ had experience teaching students with DS and over $60 \%$ had received some kind of training for teaching students with DS. The basal characteristics of both groups are described in Table 1.

Table 1. Participants' demographic characteristics

\begin{tabular}{|c|c|c|}
\hline & Experimental group $(n=37)$ & Control group $(n=11)$ \\
\hline \multicolumn{3}{|l|}{ Age n (\%) } \\
\hline $21-30$ & $3(8.1)$ & $1(9)$ \\
\hline $31-40$ & $10(27)$ & $3(27.3)$ \\
\hline $41-50$ & $7(18.9)$ & $3(27.3)$ \\
\hline $51-60$ & $10(27)$ & $2(18.2)$ \\
\hline $61-70$ & $4(10.8)$ & $2(18.2)$ \\
\hline Other & $3(8.1)$ & $0(0)$ \\
\hline \multicolumn{3}{|l|}{ Role, n (\%) } \\
\hline Teacher & $17(45.9)$ & $9(81.8)$ \\
\hline Assistant & $18(48.6)$ & $1(9)$ \\
\hline Unknown & $2(5.4)$ & $1(9)$ \\
\hline \multicolumn{3}{|c|}{ DS teaching experience in years, $n$ (\%) } \\
\hline Between 0 and 5 & $23(62.2)$ & $9(81.8)$ \\
\hline Between 6 and 10 & $5(13.5)$ & $0(0)$ \\
\hline Between 11 and 15 & $0(0)$ & $0(0)$ \\
\hline Between 16 and 20 & $0(0)$ & $0(0)$ \\
\hline Over 20 & $1(2.7)$ & $2(18.2)$ \\
\hline No experience & $8(21.6)$ & $0(0)$ \\
\hline \multicolumn{3}{|c|}{ Personal experience of DS, $n(\%)$} \\
\hline Yes & $18(48.6)$ & $7(63.6)$ \\
\hline No & $17(45.9)$ & $4(36.4)$ \\
\hline Other & $1(2.7)$ & $0(0)$ \\
\hline Unknown & $1(2.7)$ & $0(0)$ \\
\hline \multicolumn{3}{|c|}{ Formal DS training, n (\%) } \\
\hline Yes & $4(10.8)$ & $7(63.6)$ \\
\hline No & $33(89.2)$ & $4(36.4)$ \\
\hline
\end{tabular}

Caption: DS=Down Syndrome 
There were no significant differences in the global score of the CAEASD questionnaire (made up of the EASD and EEASD scales) pre- and post-intervention. This applied to both the control group $(p=0.225)$ and the experimental group $(p=0.388)$. There was less variation in experimental group's scores after intervention (Table 2), given that they had a lower interquartile range than the control group.

Table 2. Average and 25 and 75 percentile scores in the Attitudes Towards And Academic Expectations For Down's Syndrome Students (CAEASD) survey and on the Academic Expectations For Students With Down's Syndrome (EEASD) scale, before and after the intervention carried out on teachers and teaching assistants

\begin{tabular}{|c|c|c|c|c|c|c|}
\hline & \multicolumn{3}{|c|}{ Control group } & \multicolumn{3}{|c|}{ Experimental group } \\
\hline & $\begin{array}{c}\text { Pre- } \\
\text { intervention } \\
\text { average } \\
\text { (p25-p75) }\end{array}$ & $\begin{array}{c}\text { Post- } \\
\text { intervention } \\
\text { average } \\
\text { (p25-p75) }\end{array}$ & $p$-value ${ }^{a}$ & $\begin{array}{c}\text { Pre- } \\
\text { intervention } \\
\text { average } \\
\text { (p25-p75) }\end{array}$ & $\begin{array}{c}\text { Post- } \\
\text { intervention } \\
\text { average } \\
\text { (p25-p75) }\end{array}$ & $\mathrm{p}$-value ${ }^{\mathrm{a}}$ \\
\hline \multicolumn{7}{|l|}{ CAEASD scores } \\
\hline Global score & $\begin{array}{c}3.69 \\
(3.42-3.87)\end{array}$ & $\begin{array}{c}3.65 \\
(3.26-3.84)\end{array}$ & 0.225 & $\begin{array}{c}3.61 \\
(3.32-4.10)\end{array}$ & $\begin{array}{c}3.74 \\
(3.58-3.81)\end{array}$ & 0.388 \\
\hline Emotions subscale & $\begin{array}{c}3.90 \\
(3.60-4.30)\end{array}$ & $\begin{array}{c}3.80 \\
(3.40-4.40)\end{array}$ & 0.079 & $\begin{array}{c}4.20 \\
(3.60-4.60)\end{array}$ & $\begin{array}{c}4.40 \\
(3.80-4.60)\end{array}$ & 0.115 \\
\hline Actions subscale & $\begin{array}{c}3.37 \\
(3.06-3.50)\end{array}$ & $\begin{array}{c}3.38 \\
(2.88-3.63)\end{array}$ & 0.114 & $\begin{array}{c}3.38 \\
(2.88-3.63)\end{array}$ & $\begin{array}{c}3.75 \\
(3.5-4.0)\end{array}$ & $<0.05$ \\
\hline Beliefs subscale & $\begin{array}{c}3.50 \\
(2.90-3.60)\end{array}$ & $\begin{array}{c}3.30 \\
(3.00-3.50)\end{array}$ & 0.786 & $\begin{array}{c}3.40 \\
(3.00-3.90)\end{array}$ & $\begin{array}{c}3.15 \\
(3.10-3.30)\end{array}$ & 0.100 \\
\hline \multicolumn{7}{|l|}{ EEASD score } \\
\hline Global score & $\begin{array}{c}4.13 \\
(3.88-4.25)\end{array}$ & $\begin{array}{c}3.88 \\
(3.88-4.50)\end{array}$ & 0.500 & $\begin{array}{c}4.00 \\
(3.50-4.38)\end{array}$ & $\begin{array}{c}4.13 \\
(3.88-4.25)\end{array}$ & 0.211 \\
\hline
\end{tabular}

aObtained using Wilcoxon's signed-rank test.

The pre- and post-intervention scores in the three subscales that make up the EASD scale can be seen in Table 2. The significant difference between preand post-intervention stands out in the experimental group's actions subscale $(p<0.05)$. The differences in this group's emotions $(p=0.115)$ and beliefs $(p=0.100)$ subscales were not statistically significant. The control group did not exhibit any significant differences in any of the three EASD subscales.
The pre- and post-intervention scores in the academic expectations subscale can be seen in Figure 3 . In the control $(p=0.500)$ and the experimental group $(p=0.211)$, the difference pre- and post-intervention was not statistically significant.

When comparing the magnitude of the pre- and post-intervention differences, it was determined that there were no significant differences $(p=0.233)$ in the CAEASD questionnaire's global scores. However, the higher number of scores with positive changes (a difference over 0 points) stands out in the experimental group (Figure 1). 


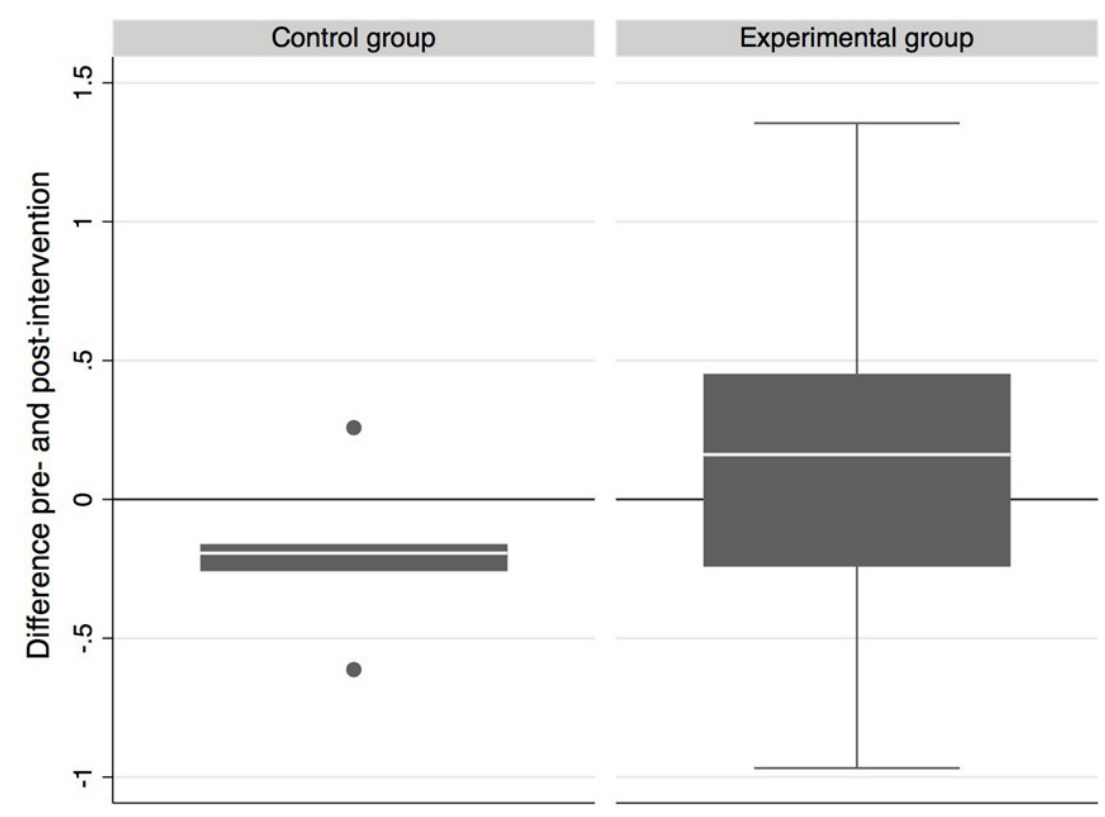

Figure 1. Intragroup differences in the Attitudes Towards And Academic Expectations For Down's Syndrome Students (CAEASD) scores before and after the intervention carried out on teachers and teaching assistants

The differences in pre- and post-intervention scores on the EASD scales can be seen in Figure 2. The greater (pre- and post-intervention) difference obtained in the emotions $(p<0.05)$ and actions $(p<0.05)$ subscales stands out in the experimental group. The differences in the beliefs subscale $(p=0.573)$ were not statistically significant though.

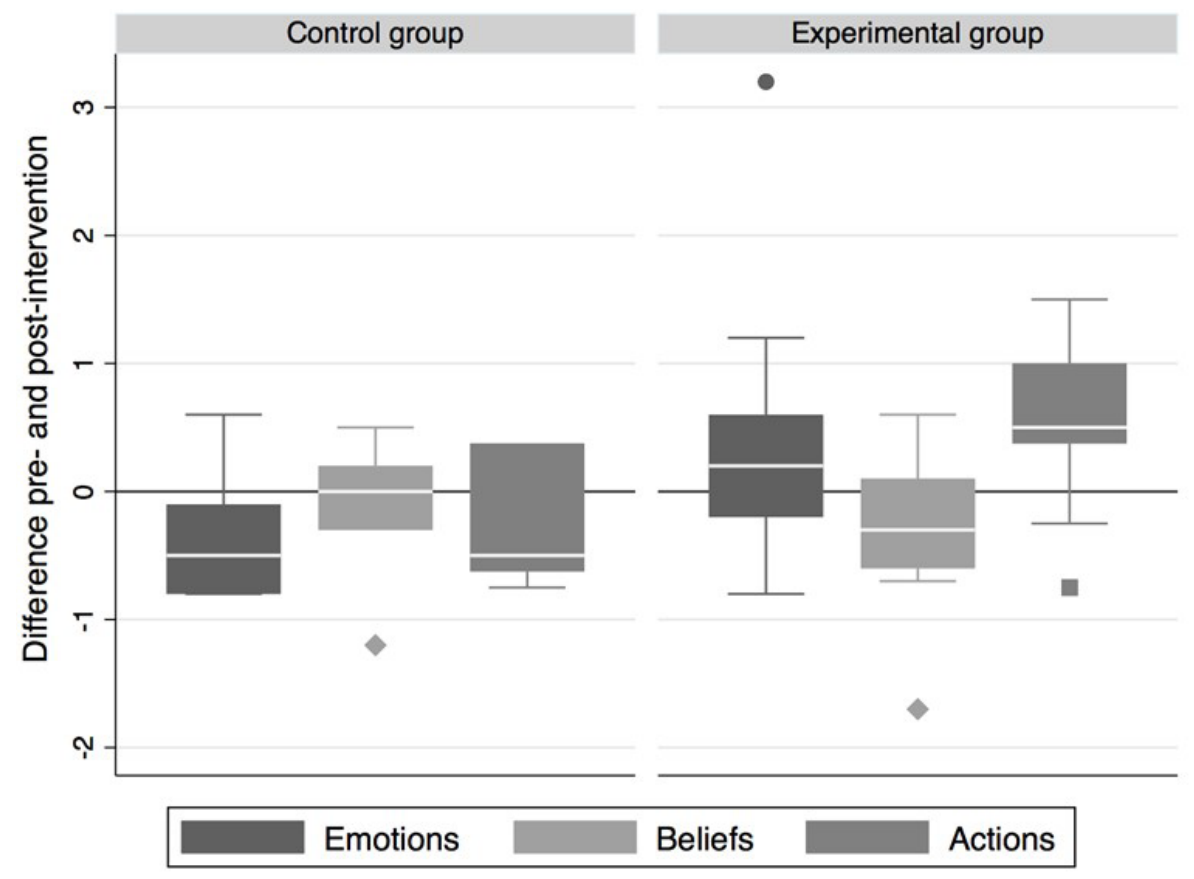

Figure 2. Intragroup differences in the Academic Expectations For Students With Down's Syndrome (EEASD) scale scores before and after the intervention carried out on teachers and teaching assistants 
The magnitude of the pre- and post-intervention differences in academic expectations can be seen in Figure 3. The comparison between the experimental and the control group for pre- and post-intervention differences was not statistically significant $(p=0.198)$.

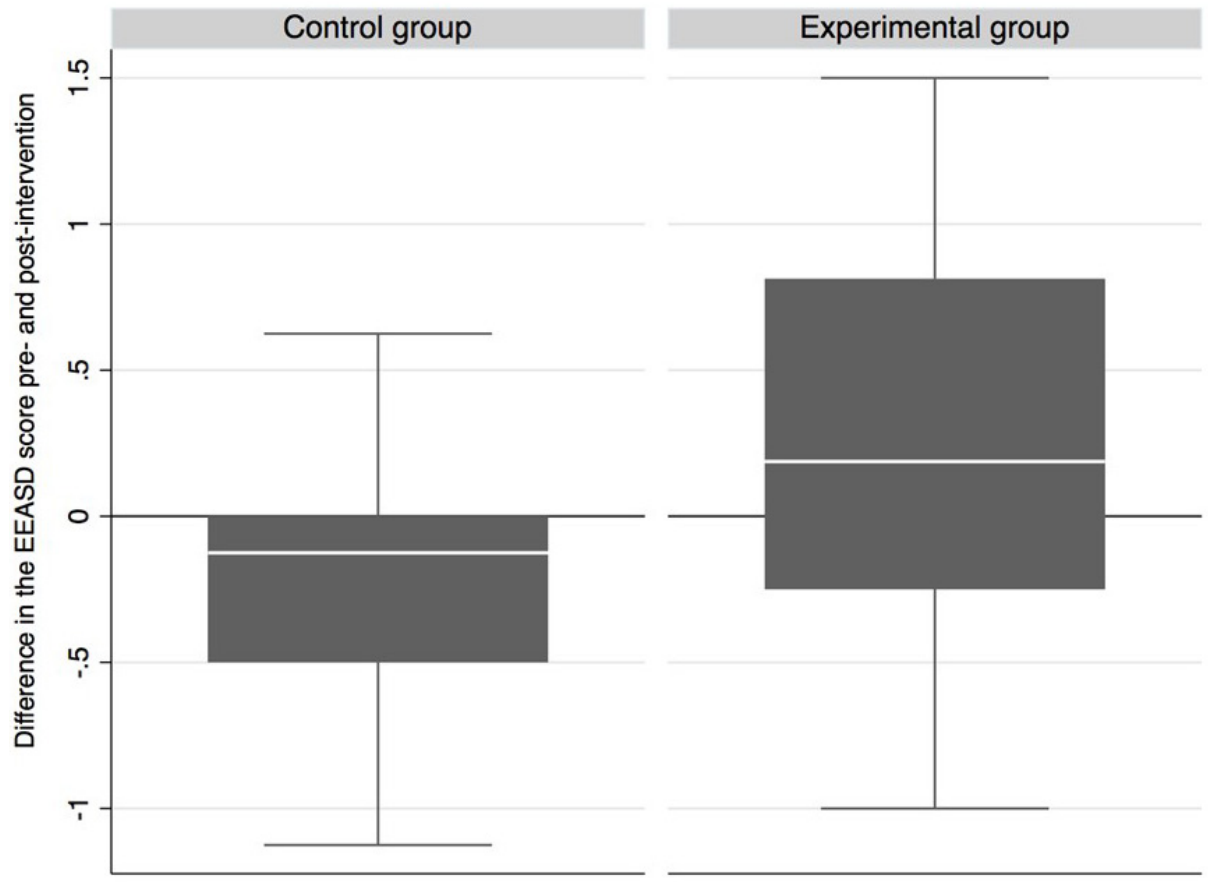

Figure 3. Intragroup differences in the Academic Expectations For Students With Down's Syndrome (EEASD) scale score before and after the intervention carried out on teachers and teaching assistants

The high scores obtained in the satisfaction survey carried out on the group stand out (see Table 3). Statements number two, nine and ten did not vary at all, each getting the highest score of five points (corresponding to the alternative 'very much agree'). For the rest of the 25 percentile, the score was four points (corresponding to the alternative 'agree'), with the average being five points.

Table 3. Descriptive (average and 25 and 75 percentile) statistics from the satisfaction survey of those who took part in the workshops

\begin{tabular}{lcc}
\hline Claims & Average & P25-P75 \\
\hline 1. The workshops helped me recognize the characteristics of students with Down's Syndrome. & 5 & $4-5$ \\
2. The workshops helped me recognize inclusive strategies that I already use in the classroom to encourage & 5 & $5-5$ \\
different students' learning. & & \\
3. The workshops helped me find out more about new strategies and resources to help students with & 5 & $4-5$ \\
Down's Syndrome learn. & 5 & $4-5$ \\
4. The content of the workshops were relevant and & 5 & $4-5$ \\
well-chosen. & 5 & $4-5$ \\
5. The teaching methods used helped me learn during the workshops. & 5 & $4-5$ \\
6. The resources used were of a high quality and relevant to the topic being taught. & 5 & $4-5$ \\
7. The workshops were generally well-organized and encouraged participant participation. & 5 & $4-5$ \\
8. The amount of time dedicated to each aspect of the workshops was adequate and appropriate. & 5 & $5-5$ \\
9. The speakers were approachable and created a pleasant environment for participation and learning. & 5 & $5-5$ \\
10. The speakers were knowledgeable about the topic and clear when imparting content. & 4.9 & $4.5-5$ \\
\hline Overall survey score & &
\end{tabular}




\section{DISCUSSION}

The aim of this study was to evaluate the effect of an intervention on teachers' and teaching assistants' attitudes and academic expectations concerning the inclusion of students with Down's Syndrome in schools. The intervention held was made up of three theoreticalpractical workshops. There were no significant differences pre- and post-intervention in the intragroup comparisons. However, when comparing pre- and post-intervention changes between the groups, these were greater in the experimental group. In addition, the number of atypical cases or outliers with negative attitudes went down in the intervened group. Although the global differences were not significant, this could be explained by the intervened group's move towards a more critical and realistic attitude.

After the intervention, there were significant changes in the behavioral component of attitude (on the action subscale). This could be related to participant empowerment, which probably improved because of the new inclusive strategies taught. In other words, the educational team identified new tools to help them deal with students with DS. This is in agreement with that observed in Mexico and Singapore where, after the intervention, the participants said they felt more receptive to diversity ${ }^{21}$ and their attitudes improved ${ }^{19}$.

The changes to the actions subscale after the intervention also reflect the fact that the participants became more aware that their actions have significant repercussions on the inclusion of students with DS. It is likely that the educational teams came to understand that their decisions both go beyond and have an impact on students' lives. Actions, as opposed to beliefs and emotions, involve behavior. Actions are also the most relevant component of attitudes ${ }^{7}$, since they are not limited to personal realities but transcend to a shared one, becoming a key component to achieving inclusion successfully.

It is important to highlight that the heads of the intervened schools also took part in the intervention, motivating their educational teams to show an interest in the topic and become actively involved in the workshops. It is thought that this helped create a favorable environment for the intervention and created a positive attitude among the educational teams ${ }^{27}$. Administrative backing makes teachers feel supported and that they are working in a collaborative environment, making them more open to using new educational tools and more likely to act in favor of inclusion ${ }^{5}$.
On the other hand, in spite of the fact that the scores on the emotions subscale, which involves the affective component, went up more than those on the beliefs one (the cognitive component), there are no significant differences in these components post-intervention. Both components are broadly related and conditioned by the participants' predisposition and prior experiences. It has been reported that teachers facing a new situation can show resistance to change because of a fear of the unknown, as well as past experiences of failure, which leads to a negative predisposition and makes it difficult to change attitudes ${ }^{28}$. In addition, these are deep-rooted beliefs, so changing an attitude involves moving out of their comfort zone ${ }^{5}$.

By only showing differences in attitudes' behavioral component, this study contradicts Campbell and Gilmore's ${ }^{20}$ results, since they observed that an effect of intervention was that beliefs towards people with DS improve. Post-intervention, participants knew more details about DS, thus destroying the stereotypes relating to learning. They concluded that attitudes to disability and the inclusion of students with DS could be changed by combining theoretical instruction with structured practical experiences. These teaching methods would give people an experience full of significance, which would improve their attitude ${ }^{23}$. This partly explains the differences with this study, which did not involve direct intervention with people with DS.

On the other hand, the talk for the control group was not enough to change their attitudes (in any of the components) or expectations. This type of teaching method is not the most appropriate for changing a person's vision or predisposition towards students with DS. It is a short-term educational opportunity, in which the listener plays a passive role and, since it was only held once, its content was not reinforced ${ }^{29}$. On the other hand, it has been reported that, when there is regular instruction with participants learning both actively and practically, there is an improvement in attitudes towards inclusion. This explains why it had less effect on this group than on the one that took part in the program with three workshops ${ }^{5,21}$.

The educational teams' academic expectations for students with DS did not change in either group. This is explained by the initial results reaching a ceiling - in other words, expectations were high in both groups and the intervention was not expected to have a significant effect on them. On the other hand, the intervened establishments have school integration programs, and over $70 \%$ of participants in both groups had between 
one and ten years of experience working with children with DS. These types of school, in which the educational team has more experience with inclusion, tend to have higher academic expectations for students with SEN ${ }^{30}$.

One of the limitations of this study is that it did not include a structured opportunity for practical experience and direct contact with people with DS as part of the intervention, something associated with better attitudes ${ }^{23}$. However, since this research is focused on establishments with students with DS, the educational teams do have direct contact with them on a daily basis as part of their job. On the other hand, it would have been a good idea to hold a focus group to find out more about participants' opinions about the intervention and the self-perceived impact on their own attitudes and academic expectations. This kind of qualitative teaching methodology promotes discussion and reflection ${ }^{31}$. Nevertheless, a satisfaction survey was taken, which allowed for some of this information to be gathered. Regarding the study's design, it is important to mention that the sample size was small and that the sample was not randomized, which interferes with internal validity. In addition, it would have been interesting to relate some of the demographical variables, such as gender or years of personal experience with people with DS, with the results obtained in the CAEASD survey. However, since it was a pilot project aimed at obtaining an initial reading of the effectiveness of this intervention, these factors are less decisive.

Given that the intervention carried out led to improvements in the behavioral component of attitudes, it is hoped that these results will be of use beyond the educational community. Speech therapists should be encouraged to use introspection and critique their fundamental role in education, as well to adopt strategies that lower barriers and favor inclusion. Therefore, extending this intervention to other educational centers and establishments to teach other educational teams how to act could be suggested.

Finally, in spite of the intervention's positive results among teachers and teaching assistants, these should be interpreted with caution. Attitudes may be influenced by contextual or structural variables, including the way the educational system and associated public policies are organized and by differentiating them from other countries in the region. Although there are School Integration Programs made up of interdisciplinary teams in Chile that provide resources, strategies and support for students with SEN ${ }^{25}$, the majority of schoolchildren with permanent SEN continue to attend special needs schools ${ }^{32}$. This hybrid system may mean that teachers' basal attitudes in Chile differ to those of other countries.

In Brazil, on the other hand, as a result of the National Policy For Special Education From An Inclusive Education Perspective, key guidelines were set out in $2008^{33}$ to establish an inclusion process for people with disabilities in both public and private schools. This has led to a progressive decrease in the number of special needs schools since $2008^{34}$, as opposed to Chile, where special needs schools have increased by $120 \%$ over ten years ${ }^{35}$. To implement the Brazilian inclusion policy, Law 13,005, passed in 2014, made inclusive education universal for children aged between 4 and 17 years old with disabilities and global development disorders. This law aims to ensure access to both basic and specialist educational, preferably within the normal education network, guaranteeing an inclusive educational system, classrooms with multifunctional resources and specialized classes, schools or services, in either the public or private sector, thus putting an end to special needs schools ${ }^{36}$. Therefore, this kind of intervention would be better implemented in countries whose way of organizing the educational system and its associated policies are similar to Chile's. However, a suggestion for future studies is to clarify whether the intervention strategies used in this study are effective in contexts where inclusion is more extensive, such as Brazil.

\section{CONCLUSION}

In this study, the effect of an intervention on the attitudes and academic expectations of teachers and teaching assistants, towards the inclusion of students with DS, in schools, was evaluated. There was a significant increase in the behavioral component of attitudes, which reflects the educational teams' willingness to draw up strategies to include students with DS. The results of this pilot study, which reports on the effect of an interdisciplinary intervention, could be the basis for future interventions aimed at encouraging the development of an inclusive educational community.

\section{ACKNOWLEDGEMENTS}

The authors would like to thank the teachers and teaching assistants at the municipal establishments in the San Bernardo neighborhood of Santiago, who took part in this study. They would also like to thank 
the heads of these schools for letting them use their premises and for allocating the time to carry out the intervention.

\section{REFERENCES}

1. American Speech-Language-Hearing Association (ASHA). Roles and Responsibilities of SpeechLanguage Pathologists in Schools. [Homepage on the internet] 2010 [accessed $2021 \mathrm{Jul} 10$ ]. Available at: https://www.asha.org/policy/PI2010-00317/

2. Rappoport Redondo S, Echeita G. El docente, los profesionales de apoyo y las prácticas de enseñanza: Aspectos claves en la configuración de aulas inclusivas. Perspect. Educ [Homepage on the internet]. 2018 [accessed 2021 Sep 23]; 57(3):3-27. DOI: $\quad 10.4151 / 07189729-V o l .57-I s s .3-A r t .740$. Available at: http://perspectivaeducacional.cl/index. php/peducacional/article/view/740

3. Díaz González CB, Larreal Bracho AJ. Avances legales, teóricos y curriculares en materia de inclusión de niños con síndrome de down y otras discapacidades. Ciencia Latina [Homepage on the internet]. 7 de agosto de 2021 [accessed 2021 Sep 16];5(4):5479-95. Available at: https:// www.ciencialatina.org/index.php/cienciala/article/ view/702

4. Karlsudd PI. The search for successful inclusion. Disability, CBR \& Inclusive Development. [Homepage on the internet] 2017 [accessed 2021 sep 23]; 28(1):142-60. Available at: http://urn.kb.se/ resolve?urn=urn:nbn:se:Inu:diva-65210

5. González Rojas Y, Triana Fierro DA. Actitudes de los docentes frente la inclusión de estudiantes con necesidades educativas especiales. Educ y Educ. 2018;21(2):200-18.

6. Diez Patricio A. Más sobre la interpretación (II). Ideas y creencias. Rev Asoc Esp Neuropsiquiatr. 2017;37(131):127-43.

7. Ruiz Rodríguez E. Programación educativa para escolares con síndrome de Down. Fundación Iberoamericana Down 21. [Homepage on the internet]. 2012. [accessed 2020 Oct 13]; 1-60. Available at: https://www.down21.org/libros-online/ libroEmilioRuiz/libroemilioruiz.pdf.

8. Hernández J, Zamora R, Lupiáñez JL. Estudio comparativo de los significados y expectativas del currículo oficial. PNA. 2020;14(4):241-69.

9. Mares Miramontes A, Martínez Llamas R. Concepto y expectativas del docente respecto de sus alumnos considerados con necesidades educativas especiales. Rev Mex Investig Educ. 2009;14(42):969-96.

10. Hughes J. Inclusive education for individuals with Down syndrome. Down Syndrome News and Update. [Homepage on the internet] 2006. [accessed 2021 Oct 9]; 6(1):1-3. Available at: https://library. down-syndrome.org/en-gb/news-update/06/1/ inclusive-education-individuals-down-syndrome/

11. Lebeer J. Schooling of children with Down syndrome: a difficult struggle towards inclusive education. Tijdschr van Belgische Kinderarts. [Homepage on the internet]. 2012 [accessed 2020 Oct 9]; 14(2):50-4. Available at: https://hdl.handle. net $/ 10067 / 1047850151162165141$

12. Bills KL, Mills B. Teachers' perceptions towards inclusive education programs for children with Down syndrome. J Res Spec Educ Needs. 2020;20(4):343-7.

13. McFadden A, Tangen D, Spooner-Lane R, Mergler A. Teaching children with Down syndrome in the early years of school. Australas $\mathrm{J}$ Spec Educ. 2017;41(2):89-100.

14. Villouta EV. Facilitadores y barreras del proceso de inclusión en educación superior: Estud Pedagógicos. 2017;43(1):349-69.

15. Gonzalez-Gil F, Martín-Pasto E, Poy Castro R. Educación inclusiva: barreras y facilitadores para su desarrollo. Un estudio desde la percepción del profesorado. Rev. actual. investig. Educ. 2020;20(2):1-27.

16. Mosia P. Threats to inclusive education in Lesotho: an overview of policy and implementation challenges. Africa Educ Rev. 2014;11(3):292-310.

17. Bradbury A, Roberts-Holmes G. The datafication of primary and early years education: playing with numbers. 1st ed. Routledge. 2017.

18. Fernández Batanero JM, Benítez Jaén $A M$, Montenegro Rueda M, García Martínez I. Do regular schools in Spain respond to the educational needs of students with Down syndrome? J Child Fam Stud [Homepage on the internet]. 2020 [accessed 2021 Sep 16]; 29(9):2355-63. Available at: https://search-ebscohost-com. pucdechile. idm.oclc.org/login.aspx? direct $=$ true $\& d b=$ asn\&AN $=145047278 \&$ lang = es\&site $=$ ehost-live

19. Li C, Wu Y, Ong Q. Enhancing attitudes of college students towards people with intellectual disabilities through a coursework intervention. J Dev Phys Disabil. 2014;26:793-803. 
20. Campbell J, Gilmore L, Cuskelly M. Changing student teachers' attitudes towards disability and inclusion. J Intellect Dev Disabil. 2003;28(4):369-79.

21. Serrato Almendárez L, García Cedillo I. Evaluación de un programa de intervención para promover prácticas docentes inclusivas. Rev. Actual. Investig. Educ. [Homepage on the internet]. 2014 [accessed 2020 Sep 14]; 14(3):1-25. Available at: http://www. scielo.sa.cr/pdf/aie/v14n3/a15v14n3.pdf

22. Lindsay S, Edwards A. A systematic review of disability awareness interventions for children and youth. Disabil Rehabil. 2013;35(8):623-46.

23. Rooney N. Promoting positive attitudes toward individuals with down Syndrome: The relationship between indirect contact interventions and the quality of previous contact. Psychology Honors Projects. Paper 34. [Homepage on the internet]. 2014. [accessed 2020 Sep 14]; 1-71. Available at: https://digitalcommons.macalester. edu/psychology_honors/34

24. Data Chile. [Homepage on the internet]. 2017 [accessed 2021 jan 23]. Available at: https:// datachile.io.

25. Decreto 170: Fija normas para determinar los alumnos con necesidades educativas especiales que serán beneficiarios de las subvenciones para educación especial. Chile. Ministerio de educación. [[Homepage on the internet] 2009. Available at: http://bcn.cl/2im60

26. Muñoz Montes M, Pozo Tapia F, Rivera Bahamonde C, Gutiérrez Oyarce A, Mora-Castelletto V, León Hopfenblatt $C$ et al. Actitudes y expectativas de aprendizaje sobre estudiantes con síndrome de Down: validación de un instrumento. Perspect. Educ. [Homepage on the internet]. 2021 [accessed 2021 Jul 10]; 60(2):48-74. Available at: http://dx.doi. org/10.4151/07189729-vol.60-iss.2-art.1181

27. Ávila Gómez M. Capítulo Políticas de educación inclusiva ¿lo estamos haciendo bien? In: Moreno Rodríguez R, Tejada Cruz A, editors. Atención a la diversidad e inclusión educativa: implicaciones didácticas. Colección iAccessibility La Ciudad Accesible. 2018;15:201-26.

28. González M del C, Tarragó Montalvo C. Capacitación para el cambio. ACIMED. [Homepage on the internet] 2008 [accessed 2020 Sep 7]; 17(4):1-10. Available at: http://scielo.sld.cu/ scielo.php?script $=$ sci_arttext \&pid $=$ S1024$94352008000400002 \& \operatorname{lng}=\mathrm{es}$
29. Candelo C, Ortiz GA, Unger B. Hacer talleres: Una guía práctica para capacitadores. Fondo Mundial para la Naturaleza. [Homepage on the internet]. Cali, Colombia: WWF Colombia, InWEnt, IFOK; 2003. [accessed 2021 jan 23]; 1-204. Available at: https://awsassets.panda.org/downloads/hacer talleres_guia_para_capacitadores_wwf.pdf

30. de Graaf G, van Hove G, Haveman M. More academics in regular schools? The effect of regular versus special school placement on academic skills in Dutch primary school students with Down syndrome. J Intellect Disabil Res. 2011;57(1):21-38.

31. O Nyumba T, Wilson K, Derrick CJ, Mukherjee N. The use of focus group discussion methodology: Insights from two decades of application in conservation. Methods Ecol Evol. 2018;9(1):20-32.

32. Vásquez-Orjuela D. Políticas de inclusión educativa: Una comparación entre Colombia y Chile. educ. educ. [Homepage on the internet] 2015. [accessed 2021 Feb 12]; 18(1):45-61. Available at: http://www.scielo.org.co/scielo. php? pid $=$ S012312942015000100003\&script $=$ sci abstract\&tlng $=$ es.

33. Pereira Dutra C, Maffini Griboski C, de Oliveira Alves D, Marangon Barbosa $\mathrm{K}$, do Nascimento Osório AC, Baptista CR et al. Política nacional de educação especial na perspectiva da educação inclusiva. Revista Inclusão. [Homepage on the internet] 2008 [accessed 2021 May 14]; 4(1):7-17. Available at: http://portal.mec.gov.br/arquivos/pdf/ politicaeducespecial.pdf

34. Baptista CR. Política pública, educação especial e escolarização no Brasil. Educ. Pesqui. [Homepage on the internet] 2019 [accessed 2021 May 14]; 45. Available at: http://www.scielo. $\mathrm{br} /$ scielo.php?script $=$ sci_arttext $\&$ pid $=$ S151797022019000100407\&tlng $=\mathrm{pt}$

35. Cardoso Garcia RM, López V. Políticas de educación especial en Chile (2005 - 2015): continuidades y cambios. Rev. bras. educ. espec. [Homepage on the internet] 2019 [accessed 2021 May 14]; 25(1):1-16. Available at: http://www.scielo. $\mathrm{br} / \mathrm{scielo}$. php? script $=$ sci_arttext\&pid $=$ S1413$65382019000100001 \&$ tIng $=$ pt

36. Plano Nacional de Educação Lei no 13.005. Brasil. [Homepage on the internet] 2014. Available at: http://pne.mec.gov.br/18-planos-subnacionaisde-educacao/543-planonacional-de-educacaolei-n-13-005-2014. 


\section{APPENDIX 1}

\section{Supplementary Table. Intervention strategies used in the workshops}

\begin{tabular}{|c|c|c|c|c|}
\hline & Aim & Content & Methodology & Materials \\
\hline $\begin{array}{l}\text { Workshop } 1^{*} \text { : } \\
\text { Inclusive education for } \\
\text { students with Down's } \\
\text { Syndrome }\end{array}$ & $\begin{array}{l}\text { To reflect } \\
\text { on inclusion } \\
\text { and Down's } \\
\text { Syndrome. }\end{array}$ & $\begin{array}{l}\text { The concepts of inclusion, } \\
\text { special educational needs } \\
\text { and the characteristics } \\
\text { of people with Down's } \\
\text { Syndrome. }\end{array}$ & $\begin{array}{l}\text { The workshop started with an activity } \\
\text { involving mime. Theoretical content } \\
\text { was then mentioned about inclusion } \\
\text { in education. There was a practical } \\
\text { activity to dispel the myths about } \\
\text { Down's Syndrome. Finally, videos of } \\
\text { testimonies of adults with Down's } \\
\text { Syndrome were shown to encourage } \\
\text { reflection among the participants. }\end{array}$ & $\begin{array}{l}\text { PowerPoint } \\
\text { presentation, } \\
\text { speakers, } \\
\text { projector and fact } \\
\text { and fiction signs. }\end{array}$ \\
\hline
\end{tabular}

The Universal Design for Learning (UDL) was mentioned, specifically the first principle of 'Providing multiple means of

\section{Workshop 2*:}

What can we do to include students with Down's Syndrome?
To identify inclusive strategies used in the classroom. representation'. In addition, the characteristics of the learning process of people with Down's Syndrome were described, as well as strategies to make the learning of students with this condition easier.

To start, a home-made video called 'Down's Syndrome and Inclusion', was shown. Then, a trivia game was played based on its content.

Next, the UDL was addressed and a practical activity carried out to introduce the UDL's first principle. Strategies were then provided to tackle the education of students with Down's Syndrome, which were put into practice by looking at a case study. Finally, the participants were invited to reflect on the topics dealt with.

Attention was paid to the

To identify different learning opportunities to respond to diversity in the classroom. second and third principles of the UDL: 'Providing multiple means of action and expression' and

'Providing multiple means of engagement'.
Inclusive strategies for diversity
The concepts of inclusion, special educational needs, the characteristics of people with Down's Syndrome and how they learn were dealt with.

Strategies for working with and evaluating students with Down's Syndrome were also provided.
First a game was played to remind the participants of the contents mentioned in the previous workshop. Then, the remaining UDL principles were discussed. Next, the group worked together to solve a case. To finish off the training activity, the main concepts dealt with were reinforced.

The talk began by mentioning theoretical content about inclusion in education. Then, the generalities of people with Down's Syndrome were described and more detail gone into regarding how they learn, how they should be schooled and how they should be evaluated. The talk ended by reflecting on the vocabulary that should be used to refer to people with Down's Syndrome.

At the end, each participant received a brochure with supplementary material.

\footnotetext{
* In the experimental group, three theoretical-practical workshops were held on inclusive practices. Each workshop lasted approximately 90 minutes and these were held over a period of three months.

** The control group attended a 45-minute talk.
} 